\title{
THE NEED FOR STATE INTERVENTION IN THE ECONOMY AND IN PARTICULAR IN THE AGRICULTURAL SECTOR - ARGUMENTS FOR AND AGAINST
}

\author{
D. Stoyanova* \\ Department of Industrial Business and Entrepreneurship, Faculty of Economics, Trakia University, \\ Stara Zagora, Bulgaria
}

\begin{abstract}
THE PURPOSE of the present research is to examine the main author's opinions regarding the state policy and its intervention in the economy and in particular in the agricultural sector, and on this basis to draw out, systematize and summarize the main directions and arguments for and against the intervention of the state in the economy. METHODS: Based on a literature review should be grouped the different opinions of the authors studied this problem. We should make a comparative analysis of the negative and positive aspects of state intervention on the economy and taking into account the specifics of the agricultural sector. RESULTS: As a result of the research are summarized and analyzed the main tendencies and opinions about the need for state intervention in the economy. CONCLUSIONS: From the analysis made in the study, there is no unambiguous vision in the economic literature regarding the need of state intervention in the economy and agricultural sector. Despite all the arguments that are drawn against the state support, the state through its policies and measures intervenes in the financial and credit markets. Factors have been put forward to support the need of state intervention to prevent market failures such as monopolization of production, imperfect competition and others. Highlighted are examples of highly developed countries where the mixed type of governance and adequate state intervention positively affect the economy.
\end{abstract}

Key words: agriculture, state intervention, monopoly, market defects, arguments.

\section{INTRODUCTION}

The question of state intervention was put in place centuries ago, but in the 1940s it became one of the most attractive among the scientific circles, provoked by the first commercial crises. According to Mill (1), "is one of the most lively in the present time ... of the political science and practice of government ... for the reasonable limits of the functions and spheres of government." State interference has its supporters and opponents in several schools over the years that continue in the present.

Many authors have debated this controversial issue, which even today divides researchers into two opposing countries. One is firmly

\footnotetext{
*Correspondence to: Darina Stoyanova,

Department of Industrial business and entrepreneurship, Faculty of Economics, Trakia University, Stara Zagora, Bulgaria, e-mail: d_stoqnova@abv.bg
}

behind the idea that state intervention is absolutely indispensable and necessary that without it the market can not cope with its shortcomings and failures. The others are behind the idea that state intervention is redundant and its implementation only leads to adverse consequences. They believe in the "Laissez faire, laissez passez" ${ }^{1}$. Both parties have the strong ground for asserting their positions with little motivation and evidence in their support. However, state support has always been and will always be in a certain form because, through its functions, the state controls the representatives of imperfect competition (monopolies and oligopolies) and

\footnotetext{
${ }^{1}$ Translation - Let things go natural. This is the motto of economic liberalism, which actually reflects their notion of noninterference in the economy. - Slavova-Nocheva, M. 2008. Liberalization of the transport market in the Republic of Bulgaria. XVIII International Scientific Conference "Transport 2008". Scientific journal "Mechanics. Transport. Communications, Issue 8, pp. III-31-III-34
} 
maintains competition by implementing a sustainable economic policy. (2)

\section{MATERIALS AND METHODS}

The study of the arguments for the need for state intervention is carried out through a theoretical analysis of author's opinions. The aim is to examine and group together the various opinions of the authors who studied this problem and to make a comparative analysis and a critical assessment of the negative and positive aspects of the state intervention on the economy as a whole and taking into account the specifics of the agricultural sector.

\section{State interference}

Supporters of state non-intervention are neoclassists and liberals. They believe that the market is so perfect that with its "invisible hand" it can handle every task and each defect that occurs, in a cheaper and better way than with foreign and outer interference. "They agree that the path to equality and prosperity implies a maximum free market and minimal state interference." (3) While supporters of Keynesian theory believe that the market is leading to a "element" that causes chaos and disorder in the organization of the economic life with unpredictable consequences such as major losses and social inefficiencies. It is not possible to derive unambiguous opinion in the literature on the involvement and the degree of implementation of state functions. Some authors are united around the view that state intervention is expressed in regulating market processes and others that it should be the "right hand" - an assistant to the business. It is appropriate to note Sedgwick's statement (4) which we believe is applicable to the modern economy, including the agrarian sector, namely that it does not follow that "whenever the "laissez faire" policy fails, the intervention of the government is appropriate because its inevitable shortcomings can in each case be worse than the flaws of private initiative. "

Supporters of State interference produce various and important arguments in defense of their thesis. Marinova (5) believes that governments can create buffer stocks of production by buying it from the saturated market and thus preventing or mitigating the development of crises, while the private market can not afford such action. Another important argument is fundamental research that poses high risks and high costs, so they are not a priority for the private sector, whereas
SOYANOVA D.

the state can finance, in part or in full, such projects. (5)

The market itself maintains balance, but not absolutely, but partly. The task of the state at this time is to give more stability and to guarantee the community less development. The state is a correctional apparatus on the market, which requires rethinking the rules of the market mechanism. Through its functions it has to influence market relations - it can increase or decrease aggregate production in a sector and thus restore market equilibrium.

According to some authors $(2,6)$, practice shows that state intervention is more likely to be used more in the more developing countries. It is a fact that some of the best economic results have been achieved in countries where governments have actively participated and have had a strong influence on economic activity. State intervention is well targeted by promoting the efficiency of bureaucracy, investment in education, selective support for specific economic sectors and the building of sustainable and effective export-oriented policies.

According to Stiglitz (7) in developing countries, market defects are larger and the state's ability to cope with them is smaller. It identifies five key strands of the state: 1) promoting education, 2) promoting technologies supporting the financial sector, 3 ) investing in infrastructure, 4) preventing environmental degradation, and 5) creating and maintaining a social security network.

Yankov (8) states that the role of the state in the normally functioning society is based on the laws that are being created and applied. By distinguishing the functions of the state from its power, in the sense of institutional efficiency, state and administrative capacity, the author rejects the assertion that the reduction in the scope of state functions leads to a weaker state. In support of this assertion, he states that there are countries with a limited perimeter of state functions but showing strong institutional efficiency.

There are areas where, in a given productioneconomic activity, the monopoly is inevitable. There the state's intervention is imperative, and sometimes even the government is in its hands, maintaining the controlling stock of monopolistic companies. Most of the natural monopolies that exist in the present are the so- 
called state monopolies. Examples include exchange rate regulation, money laundering, arms production and sale, and others. These monopolies are an exception, and the state does not apply an antitrust policy to them, and if it does, it is in exceptional situations. The interference is the granting of licenses to carry out state-monopoly activity or on a legislative basis. (9)

On the other hand, there are many economists who are against the state intervention. Studies have shown that state intervention may be inefficient for production, the market and the economy as a whole. Some authors (10) do not support state intervention in specific sectors such as industry, but accept support to others agriculture. In their view, this disturbs the functioning of the market, resulting in a total loss of the country's wealth due to government failures.

A further argument against state intervention is the inefficient allocation of resources transferring them from one sector to another through the payment of taxes by the former. This conclusion is reached by Sakano and Obeng (11) after a study of equilibrium models.

Taking into account the complexity of market relations, Manov (12) summarizes: "The simple fact is that the market does not always work effectively," as modern life and the surrounding environment are complex, so the state's intervention is imperative. The author makes it important to state that the state must not determine everything and intervene in the management of the individual business units the enterprises, to favor one at the expense of others. Yakoka (13) and Erhard (14) also share the need for limited state intervention in the markets. In this sense, they emphasize that "it is not the state that decides who will take the market, but not an entrepreneurial organization either, such as a cartel, but an exclusive the consumer."

Despite the positive side of state aid, it is possible that these funds distort and disturb the competition on the market, so the European Union introduces some basic rules through its Competition Policy. State aid is limited, with the aim of avoiding the privilege of some of the beneficiaries. Long-term funding could lead to inefficient and unproductive sectors, thus omitting the emergence of new, more efficient and innovative industries with growth
SOYANOVA D.

potential. Simeonova (15) gives an example of taxpayers' money allocated to subsidies, they could be used in other areas (education, healthcare, etc.) or reduced and thus reduced the tax burden. Thus, it determines the need for these State aid rules in order to eliminate the abuse of competition and to realize an open and competitive market.

\section{State intervention in the agricultural sector}

The agrarian sector is traditionally supported. In it the state intervention is applied with greater force than other sectors of the economy. Discussions are conducted in the scientific literature in what form and by what mechanisms state support is applied. Vachkov and colleagues (16) synthesize different opinions and views on this issue in two approaches - traditional and innovative.

The traditionalists' approach, in turn, Brawerman and Rozenweig (17) follows the ideas of the Keynesian School supporters. Scientists are for more active state intervention in agricultural financing, focusing on direct financial interventions.

On the other hand, representatives of the innovative approach believe that this is not the most effective way to finance agriculture. Their views are for minimal interference from the state. The main objective of the state, in accordance with its intervention on the market, is to create a favorable economic and social environment in order to facilitate the proper functioning of the agricultural markets and to provide the necessary financial resources for the activity of the agricultural entrepreneurs. According to some authors (18-20), the state should encourage investment in infrastructure and stimulate investment in human resources in rural areas.

According to Yaron (19), the need for State intervention in funding in the agricultural sector is conditioned by the existence of some important barriers to its self-development as insufficient borrowing resources directed at farmers from private credit institutions; barriers of a financial nature related to the introduction of modern technologies; small, insufficient savings capacity and limited selffinancing opportunities for rural businesses.

According to some authors $(21,22)$, the main factors for state intervention in agriculture are the low competitiveness of the sector, the specificity of the value chain, the power of the 
electorate and political considerations. Other authors (23) consider that state intervention in agriculture is caused by the need to overcome market defects and the need to balance incomes of employed in different sectors of the economy. The income gap between rural and urban workers has always been positive for cities, so it is important to increase the income of rural workers. The authors propose specific government policies for the stated goal: 1) To increase the productivity of labor, which in turn leads to an increase in income and profit; 2) Increase the production of products with greater elasticity of income; 3) Co-operation and consolidation of farmers.

Park and Jensen (24) discuss the example of state intervention in the Agrarian sector through the power of the electorate and political considerations. Even in recent years, agriculture is a major livelihood in some countries in less developed regions around the world. Thus, in order to win this electorate, politicians purposefully support it in different forms and ways. Some of them even accept strong protectionism in order to achieve food security and independence, claiming that everyone must have permanent physical and financial access to food. (25)

The next reason for State interference (26) is the possibility of eliminating part of the price shocks resulting from the conditions of international markets by protecting the internal market.

According to some authors, the need for state intervention in the Agrarian sector is justified by its dependence on the natural and climatic conditions, the threat of spreading diseases and pests on crops and animals, the large time difference between capital investment and production, the dependence of productions on limited resources, such as farmland, increasing population and changing eating habits.

Contrary to the supporters of state intervention, a number of researchers argue in favor of the claim that state intervention on agrarian markets is not necessary and even leads to negative consequences. Researchers (27), who are firmly supporters of non-intervention by the state in the agrarian sector, believe that there is a distortion in providing support to farmers. Aid is mainly provided by large and consolidated enterprises, and small and medium-sized enterprises are disadvantaged. Their relaxation is related to economic losses
SOYANOVA D.

and very complex programs, the realization of which is associated with high public spending. Redirecting funds from other sectors to the agricultural sector by paying direct aid, not linked to the quantity, quality and type of output, is a good example of state intervention. If the cause of state intervention is to correct market imperfections, it is important to find and remove the source. This can be done by reducing transaction costs, regulating access to information, and more.

\section{RESULTS AND CONCLUSIONS}

While all researchers, who are not supporters of state intervention and point out different and important arguments, the functioning of market economies testifies that states support their intervention in the market through different policies and instruments. In some sectors of the economy, and in particular in the agrarian sector, its role is even stronger. In the present, discussions should not be held to have or not to have a state interference. In particular, the question we need to find an answer is in what form and by what mechanisms the state intervenes on the market. We adhere to Manov's view (12) that there is an objective necessity for state intervention in the functioning and development of the economy, but only in some spheres and in a certain form. Obviously, neither extreme side, for or against, is the right choice. Security in the economy is relative, and both sides are at some time united in the claim that the allocation of state support should be optimal.

\section{REFERENCES}

1. Mill J.St., Basics of Political Economy. T. III, Progres - Moscow, 1981.

2. Coklinova, M., Modern dimensions of state intervention in market relations: stimulating the competitive environment and economic growth. National Conference of UNWE "Economic Challenges: Growth, Imbalances, Sustainable Development", 6 November 2015, pp. 88-95, 2015.

3. Braikova, T., Theory of Social Policy. „Paradigma”, 2000.

4. Sidgiwick, H., Principles of Political Economy. MacMillan, London, 1887.

5. Marinova, Nadya, The problems of unifying the conditions of competition in the European Union. Eleventh International Scientific Conference of Young Scientists, 15 December 2015, UNWE, Sofia, Bulgaria, 2015. 
6. Baev, Iv., Sustainable development policy, public welfare and public choice. Sofia, UNWE, 2006

7. Stiglitz, J., The cost of inequality. „IztokZapad", pp. 542, 2014.

8. Yankov, G., Bulgarian Statehood after the Liberation (1878) and the beginning of the XXI century: comparative analysis. Epohi 2: 181-195, 2012.

9. Stoichkova, Og., The role of the state in regulating competition in the market. Journal of Science "New Knowledge" Jubilee Edition 2017, funded by the Scientific Research Fund, Higher School of Agribusiness and Regional Development Plovdiv, 2017.

10.Peacocak, A. T., Identifying and applying norms for subsidies to industry. Producer Subsidies, (ed.) Ronald Gerritse, Pinter Publisher, Londres: 20-31, 1990.

11.Sakano, R., y Obeng, K., Subsidies and inefficiency: stochastic frontier approach. Contemporary Economic Policy, julio, vol. 15 issue 3: 113-128, 1997.

12.Manov, V., The role of the state in the economy, 2008.

13. Yakoka, L., Autobiography. "NI", IK Hristo Botev, 1994.

14.Erhard, L., Prosperity for all. UI stopanstvo, pp. 155, 1993.

15.Simeonova, G., Fiscal State Aid. A Yearbook of the Law Department, 6:248259, 2016.

16. Vachkov, St., Em. Spasova-Yanakieva and D. Petrov, Bank lending to the agrarian business - risks and alternatives. „Nauka i ikonomika", UE - Varna, 2004.

17.Braverman, A. and M. Rozenweig., Rural credit markets and institution in developing countries: lessons for policy analysis from practice and modern theory. World development 10, p. 1253-1267, 1986.

18.Binswanger, H. and M. Rosenweig., Wealth, weather, risk and the composition of agricultural credit investments. World bank agricultural operations division, Washington DC, 1989.
SOYANOVA D.

19. Yaron, J., Rural finance. Issues, design and best practice. The World Bank, Washington D.C., p. 22-23, 1997.

20.Calomiris, C., C. Himmelberg., Direct credit programs for agriculture and industry: arguments from theory and fact. World band economic review, 1993.

21.Baldwin, R., The political economy of protectionism. University of Chicago Press, 1982.

22.Anderson, K., Y. Hayami and al., The political economy of agricultural protection. Allena and Unwin, London, 1986.

23.Thies, Cameron, G. and Schuyler Porche, Political Economy of Agricultural Protection. Journal of Politics, Vol. 69, Issue 1, 2008.

24.Park, Jong Hee and Nate Jensen, Electoral Competition and Agricultural Support for OECD Countries. American Journal of Political Science, Vol. 51, Issue 2, 2007.

25.Ahluwalia, P., "The Implementation of the Right to Food at the National Level: A Critical Examination of the Indian Campaign on the Right to Food as an Effective Operationalization of Article 11 of ICESCR". Centre for Human Rights and Global Justice Working Paper No 8, 2004. NYU School of Law; Narula, S. 2006. "The Right to Food: Holding Global Actors Accountable Under International Law". Columbia Journal of Transnational Law, Vol. 44, № 3, 2004.

26. Gouel, C. and S. Jean, Optimal Food Price Stabilization in a Small Open Developing Country. The World Bank Development Research Group, Agriculture and Rural Development Team, 2011.

27.Davis, C., "Food Fights over Free Trade: How International Institutions Promote Agricultural Trade Liberalization". Princeton University Press; Anderson, K., B. Dimaranan, J. Francois, T. Hertel, B. Hoekman, W. Martin. 2001. "The costs of rich (and poor) country protection to developing countries". Centre for International Economic Studies Discussion Paper. Adelaide University, 2003. 